\title{
Variation in planulae release of closely related coral species
}

\author{
M. J. A. Vermeij ${ }^{1,2,3}$, E. Sampayo ${ }^{1}$, K. Bröker ${ }^{1}$, R. P. M. Bak ${ }^{1,2, *}$ \\ ${ }^{1}$ University of Amsterdam, IBED, PO Box 94766, 1090 GT, Amsterdam, The Netherlands \\ ${ }^{2}$ Netherlands Institute for Sea Research (NIOZ), PO Box 59, 1790 AB Den Burg, Texel, The Netherlands \\ ${ }^{3}$ Caribbean Marine Biological Insitute (CARMABI), Piscaderabaai z/n, PO Box 2090, Willemstad, Curaçao, Netherlands Antilles
}

\begin{abstract}
To determine the degree of variation in coral reproductive strategies at a low taxonomical level, we studied the planulae release pattern in 4 Madracis morphospecies, including 2 colourmorphs of 1 species. All species have the same basic planulae release strategy: colonies of all species release planulae from March to December and spawning intensity fluctuates highly at a daily scale. Two differences exist among species. Firstly, species differ in the number of planulae released, ranging between 0.02 and 0.11 planulae $\mathrm{cm}^{-2} \mathrm{~d}^{-1}$. Secondly, spawning is not related to a moon-phase for any species except for $M$. senaria. During the last quarter moon in November, $M$. senaria releases large numbers of planulae $(\mathrm{n}>1000)$. Mass release of planulae concurrent with the Caribbean mass spawning has never been reported previously for a brooding coral species. For all species examined the number of planulae produced is related to yearly seawater temperature cycles with a lag period of $1 \mathrm{mo}$, i.e. planulae production at any given month is related to the seawater temperature of the preceding month. Yearly temperature cycles dominate over lunar cycles in the regulation of planulation in Madracis spp. The number of planulae produced is not related to colony size in any species. The brooding reproductive strategy can be divided into 2 sub-strategies: (1) organized mass release, or (2) gradual release in low numbers without any conspicuous pattern. Our data show that small but significant differences exist in the reproductive strategies of closely related coral species, even at the level of colourmorphs, which differ in the fraction of spawning colonies in a population.
\end{abstract}

KEY WORDS: Reproduction · Madracis · Planulae · Brooder · Coral · Caribbean · Life history

\section{INTRODUCTION}

The reproductive behaviour of corals consists of 2 basic strategies: species either spawn large numbers of male and female gametes in the water column followed by external fertilization or they brood larvae (planulae) that are produced after internal fertilization (Harrison et al. 1984, Szmant 1986, Harrison \& Wallace 1990). However, categorization in just 2 reproductive strategies easily results in generalizations that possibly ignore relevant differences within these strategies. Temporal patterns in gamete and planulae release affect life-history aspects of a coral species, such as fertilization success, juvenile survival, adult growth and mortality patterns. Together, these life-history elements determine a species' fitness, so differences in reproductive behaviour directly affect population dynamic processes (Jokiel et al. 1985, Ward 1992, Tanner 1996, Knowlton et al. 1997, Kruger \& Schleyer 1998, Shlesinger et al. 1998).

Variation in life-history strategies is important as a possible start for evolutionary divergence (Richmond \& Hunter 1990). Small differences in life-history processes can result in speciation if the direction of change is associated with an increase in fitness (Moran 1992, Stearns 1992). This highlights the need for high resolution studies looking more closely into reproductive strategies, beyond the overall classification of brooding or spawning.

Approximately $60 \%$ of the colonial scleractinian Caribbean coral species are brooders, thus the scarcity of data on their reproductive strategies is surprising 
(Fadlallah 1983, van Moorsel 1983, Szmant 1986, van Veghel 1994, deGraaf et al. 1999). Brooding is associated with small colony size and believed to be favoured in disturbed environments (Stearns 1992, Ayre et al. 1997).

Van Moorsel (1983) showed that differences between brooding species can be very subtle. He separated Agaricia agaricites and $A$. humilis as different species based on their reproductive behaviour. The differences in Agaricia spp. reproductive strategies are related to the predictability of the habitat, suggesting that these strategies arose as different adaptational responses. For these agaricids, but also in the Montastraea sp. complex (van Veghel 1994), genetical and ecological characterization indicate the existence of considerable ecological variation within traditional morphological species boundaries. Closely related species with an uncertain taxonomical position (due to morphological similarity) therefore provide an ideal model for studying the variation in reproductive strategies.

In the Caribbean, the coral genus Madracis currently comprises 7 species, including $M$. asperula, a deepwater $(>100 \mathrm{~m}$ ) species (Wells 1973a,b, Vermeij et al. $2003 \mathrm{~b})$. The taxonomic status of 2 species, $M$. decactis and M. pharensis, is debatable (Fenner 1993, Diekmann et al. 2001). Fenner (1993) described M. decactis and $M$. pharensis as different ecotypes based on light preference. Diekmann et al. (2001) showed that only $M$. senaria and $M$. mirabilis form 'true' or monophyletic genetic species, whereas $M$. decactis, $M$. pharensis and $M$. formosa exchange genetic information and form a species complex. Mature gametes are

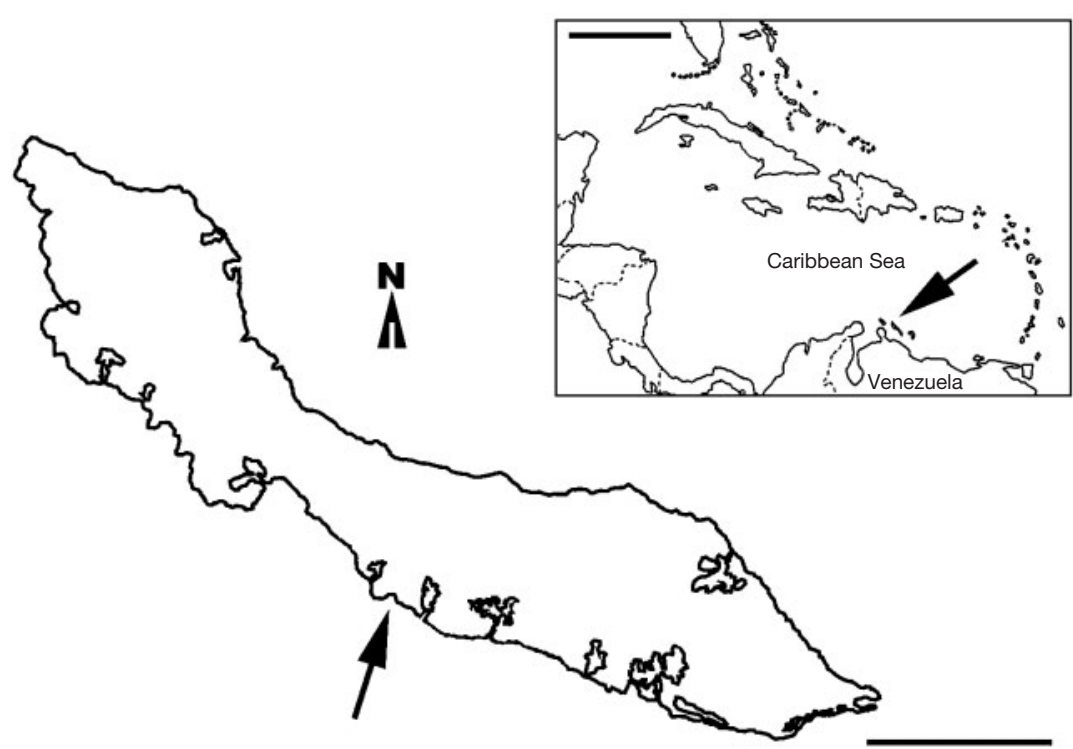

Fig. 1. Location of Curaçao and sample site Buoy Zero (arrowed); scale bars $=500$ and $10 \mathrm{~km}$ respectively present in all Madracis sp. at the same time (Vermeij et al. 2003a), which provides possibilities for hybridisation. Since hybridisation maintains genetic variation and genetic exchange between species, it plays an important role in the formation of such species complexes (Veron 1995, Kenyon 1997, Odorico \& Miller 1997). The genus Madracis therefore includes a number of morphospecies, as well as colourmorphs that differ in their relatedness. The morphological diversity from branching ( $M$. mirabilis) to encrusting ( $M$. senaria and $M$. pharensis) species and the different ecological niches they occupy provide an ideal setting for studying the relation between reproductive differences and the currently debated taxonomical classification of the genus.

\section{MATERIALS AND METHODS}

Species distinctions. We studied 4 Madracis species: $M$. decactis and $M$. pharensis were defined according to the proposed morphotypes described by Fenner (1993), M. senaria and M. mirabilis were classified according to Wells $(1973 a, b)$. Encrusting and nodular colonies were classified as M. pharensis and M. decactis respectively. Encrusting $M$. pharensis colonies occurred in different colourmorphs (Vermeij et al. 2002). The planula release of the 2 most abundant colourmorphs, brown and green, was individually investigated during the 1999 spawning season. The other Madracis species were not monitored because they occur at depths too great to be included in this study.

Collection of planulae. Planulae collections were made daily during a period of 13 mo from 18 September 1998 to 8 November 1999 at the site Buoy Zero near Piscadera Bay on the SW coast of Curaçao (Fig. 1). Plankton-gauze net traps (Nitex, 80 to $120 \mu \mathrm{m})$ were placed over Madracis spp. colonies ( $\mathrm{n}=12$ to 15 per species, colony surface $=100$ to $500 \mathrm{~cm}^{-2}$ ) at a depth range of 15 to $20 \mathrm{~m}$. Rubber bands were used to close the net traps at the bottom end. Replaceable plastic test tubes were fixed on the upper end of the coneshaped net traps (Fig. 2) where planulae concentrate after extrusion. Test tubes were collected and replaced daily in the morning (8:00 to 9:00 h) since larval release occurs at night for all species. Planulae were counted and their size was measured under a dissecting micro- 


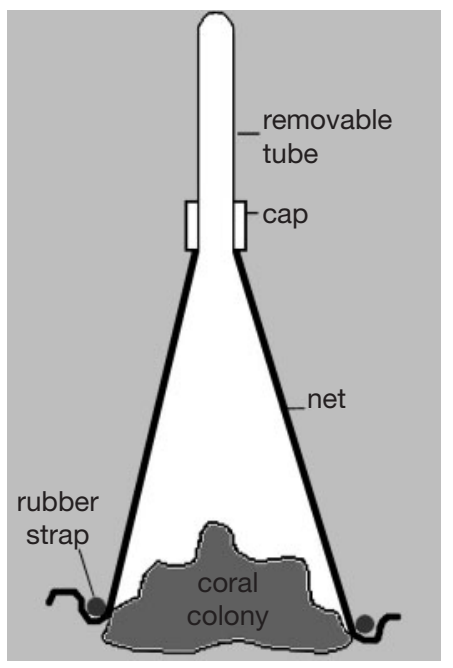

Fig. 2. Net trap used to collect planulae

scope. Occasionally, planulae (total $\mathrm{n}=32$ ) were released from the test tubes and followed visually to study their settling behaviour.

In order to prevent algal overgrowth that reduces light intensity and water flow nets were removed and cleaned every 2 wk using a $4 \%$ Clorox-solution and then rinsed in flowing water. A pilot experiment indicated that tissue degradation and colour change could occur when the nets were left over colonies for more than 4 wk. Therefore, after cleaning, the nets were placed over different colonies at the same site. All colonies sampled in this study occurred within a $54 \mathrm{~m}$ wide area between the 15 and $30 \mathrm{~m}$ isobath. The living tissue surface of the sampled colonies was measured in order to relate the release of planulae to colony surface area. Area was determined by overlying a colony with a transparent slide with black dots, marking square centimetres, and counting the number of dots covering the living tissue. Because of its branching morphology, the surface measurements of Madracis mirabilis were corrected using the aluminium foil technique (Marsh 1970): tissue area $=$ $2.83 \times$ area measured by using the sheet $\left(R^{2}=0.91\right.$, $\mathrm{n}=50$ ). The strict microhabitat preference of all morphospecies (M. decactis and M. mirabilis on exposed and $M$. senaria and $M$. pharensis on cryptic surfaces) excludes the possibility of environmental variability within one species interfering with its planula release patterns.

Tests of efficiency of the net trap method. Since Madracis spp. planulae are not described elsewhere we confirmed, using genetic characterisation (speciesspecific internal transcribed spacer sequences), that the planulae captured were indeed produced by Madracis colonies (Diekmann unpubl. data). Prelimi- nary observations on the behaviour of planulae in the tubes indicated negative geotaxis after extrusion for at least 16 to $24 \mathrm{~h}$ for all species. Consequently, planulae concentrated in the plastic tube at the top of each net. To determine the effectiveness of the net trap method, we compared the release of planulae of colonies in situ with colonies ( $\mathrm{n}=12$, each species) in aquaria following the method of McGuire (1998). Intact colonies were removed from the reef using a hammer and chisel and transported to the flow-through, outdoor aquarium system of the Caribbean Marine Biological Station in water-filled zip-lock bags within 10 min of collection. No planulae were found in the zip-lock bags after transport and planulae released in the aquaria could easily be counted with the naked eye. There was no significant difference between the 2 sampling methods (Kruskal-Wallis ANOVA, p > 0.42), indicating that the net traps can be used for quantitative planula collections on the reef.

Temperature. Seawater temperature was determined using a permanent Seamon-mini temperature logger (Hugrun) placed at $15 \mathrm{~m}$ measuring every 30 min.

Statistical analysis. Interspecific differences in planulae release (percentage spawning colonies per species per night) and spawning intensity (number of planulae produced per $\mathrm{cm}^{2}$ per species per night) were analyzed using Students's $t$-tests and Kruskal-Wallis ANOVAs. Chi-square and regression analyses were used to analyse the relationship between planulae release and lunar and temperature cycles respectively. Lunar cycles were subdivided into lunar weeks and lunar days to determine the temporal scale regulating planulae release. Each moon phase indicates the middle of a lunar week. The relationship between the number of planulae produced and colony surface area was determined using regression analysis (McGuire 1998). All statistical tests were performed using SYSTAT 10.0 (SPSS 2000).

\section{RESULTS}

\section{Planula characteristics and behaviour}

The planulae of all species are spheroid or ballshaped, but their form is plastic and changes on a minute time-scale (Fig. 3a). Only planulae of Madracis mirabilis and M. senaria were observed with a brown ring consisting of zooxanthellae at the oral end (Fig. 3b). The size of planulae differs between species (square-root transformed size data, ANOVA $_{i} F=6.90, \mathrm{df}=4, \mathrm{p}<0.001$ ), but this difference is mainly due to $M$. decactis $\left(0.038 \mathrm{~mm}^{3}\right.$; SD $0.030, \mathrm{n}=150)$ that has larger planulae $(t$-test; 


\section{a}

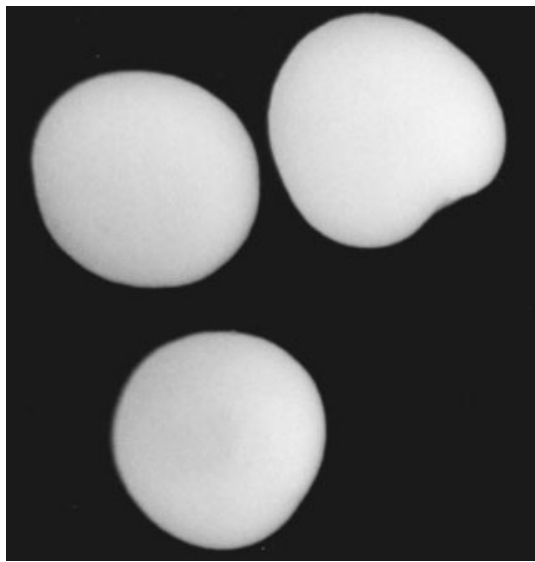

b

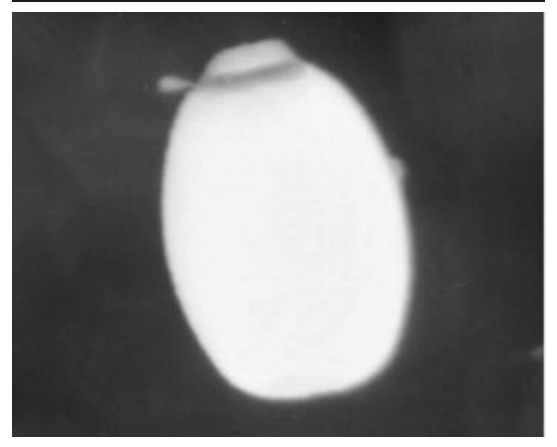

Fig. 3. Madracis spp. Planulae of: (a) M. decactis without zooxanthellae (max. diameter approx. $330 \mu \mathrm{m}$ ); (b) M. senaria with zooxanthellae (max. diameter approx. $310 \mu \mathrm{m}$ )

$t>0.37 ; \mathrm{n}>55 ; \mathrm{p}<0.003)$ than all other species (Table 1). The planulae for this comparison were obtained from different colonies $(\mathrm{n}>50)$ during the 1999 spawning season. This allowed the inclusion of the green morph of $M$. pharensis whose planulae release was monitored only during this period.

Planulae show negative geotaxis, but were never observed higher than $1 \mathrm{~m}$ above the bottom. They move in a tumbling motion at a speed of 9 to $12 \mathrm{~cm}$ $\mathrm{min}^{-1}$ and start to explore the bottom 16 to $24 \mathrm{~h}$ ( $\mathrm{n}=$ 32) after release. The planulae crawl over the reef bottom and often resume swimming for small distances $(<0.50 \mathrm{~m})$.

\section{Timing of planulae release}

Planula release occurred from April to December with maximum release from September to November for all species. Two sperm clouds were found in nets positioned over Madracis senaria colonies together with planulae in October 1998. Maximum planulae release occurred during the autumn months, from September to November. During a single night up to $67 \%$ of the colonies of $M$. senaria and $M$. mirabilis released planulae. This maximum percentage of spawning colonies was lower for the other species: $30 \%$ for $M$. decactis and $M$. pharensis (brown morph) and $20 \%$ for M. pharensis (green morph). In all species, a single colony often contributed the majority of the planulae (>90\%) during a particular night and these colonies generally released planulae over consecutive days. The longest release period (lasting $12 \mathrm{~d}$ in October 1999) was recorded for a colony of $M$. mirabilis. On average, colonies spawned between 1.1 and 1.4 consecutive days.

\section{Colony size and fecundity}

The number of planulae released (expressed as the total number of planulae produced by 1 colony in $2 \mathrm{wk}$ ) was independent of colony size in all species (Table 2). Although correlation coefficients were close to significance for Madracis decactis and the brown morph of M. pharensis, colony size contributed only 17 to $27 \%$ of the observed variation in planulae release. Species dif-

Table 2. Madracis spp. Relationship between the number of planulae released and colony size

\begin{tabular}{|lccr|}
\hline Species & $\mathrm{R}^{2}$ & $\mathrm{p}$-value & $\mathrm{n}$ \\
\hline M. decactis & 0.27 & 0.08 & 105 \\
M. senaria & 0.48 & 0.54 & 76 \\
M. mirabilis & 0.19 & 0.45 & 105 \\
M. pharensis brown & 0.17 & 0.06 & 76 \\
\multicolumn{1}{r}{ green } & 0.02 & 0.14 & 43 \\
\hline
\end{tabular}

Table 1. Madracis spp. Planulae size for all morphospecies, and ecological and genetical characteristics of adult colonies

\begin{tabular}{|c|c|c|c|c|c|c|c|}
\hline \multirow{2}{*}{ Species } & \multirow{2}{*}{$\begin{array}{l}\text { Colony } \\
\text { shape }\end{array}$} & \multirow{2}{*}{$\begin{array}{l}\text { Habitat } \\
\text { preference }\end{array}$} & \multirow{2}{*}{$\begin{array}{l}\text { Genetically } \\
\text { related to }\end{array}$} & \multirow{2}{*}{$\begin{array}{l}\text { Planulae zoo- } \\
\text { xanthellate }\end{array}$} & \multicolumn{3}{|c|}{ Planulae size } \\
\hline & & & & & Average $\left(\mathrm{mm}^{3}\right)$ & $\mathrm{SD}$ & $\mathrm{n}$ \\
\hline M. decactis & Nodular & Exposed & M. pharensis & No & 0.038 & 0.030 & 106 \\
\hline M. senaria & Encrusting & Cryptic & None & Yes & 0.021 & 0.034 & 54 \\
\hline M. mirabilis & Branching & Exposed & None & Yes & 0.021 & 0.020 & 66 \\
\hline \multirow{2}{*}{$\begin{array}{r}\text { M. pharensis brown } \\
\text { green }\end{array}$} & Encrusting & Cryptic & M. decactis & No & 0.027 & 0.035 & 56 \\
\hline & Encrusting & Cryptic & M. decactis & No & 0.029 & 0.019 & 66 \\
\hline
\end{tabular}


Table 3. Madracis spp. Planulae production as a function of surface area. Time needed for a polyp to produce a new planula calculated for polyp density of $25.1 \mathrm{~cm}^{-2}$ (for all species; $\mathrm{SD}=4.8, \mathrm{n}=180$ )

\begin{tabular}{|lccccc|}
\hline \multicolumn{7}{|c}{ M. decactis } & $\begin{array}{c}\text { M. pharensis } \\
\text { brown }\end{array}$ & $\begin{array}{c}\text { M. pharensis } \\
\text { green }\end{array}$ & M. senaria & M. mirabilis \\
\hline \multicolumn{7}{c}{ Planula release $\left(\mathrm{n} \mathrm{cm}^{-2} \mathrm{~d}^{-1}\right)$} \\
min & 0.00 & 0.00 & 0.00 & 0.00 & 0.00 \\
mean & 0.05 & 0.03 & 0.04 & 0.11 & 0.02 \\
max & 1.92 & 0.89 & 0.17 & 3.30 & 0.22 \\
SD & 0.17 & 0.09 & 0.04 & 0.41 & 0.03 \\
n (colonies) & 131 & 97 & 27 & 99 & 131 \\
Time for 1 polyp to produce a planula (in days) & & \\
min & 38750 & 10107 & 32550 & 56575 & 17825 \\
mean & 465 & 739 & 579 & 228 & 1492 \\
max & 13 & 28 & 150 & 8 & 115 \\
\hline
\end{tabular}

fered in fecundity (Table 3), expressed as the number of planulae released per $\mathrm{cm}^{2}$ per $\mathrm{d}$ for spawning colonies (ANOVA, $F=3.00$, df $=4, \mathrm{p}<0.02$ ). Subsequent post hoc tests indicated that the difference in fecundity was significant only between $M$. mirabilis and $M$. senaria ( $p$ $=0.03$ ). Based on the average number of polyps, 25.1 $\mathrm{cm}^{-2}$ (all Madracis species; $\mathrm{SD}=4.8, \mathrm{n}=180$ ), we calculated that the average time for a polyp to produce a planulae exceeds $1 \mathrm{yr}$ for all species except $M$. senaria (Table 3).

\section{Differences between 2 colourmorphs of Madracis pharensis}

The number of spawning colonies was lower for the green morph $(t$-test; $t=2.23, \mathrm{df}=453, \mathrm{p}<0.01$ ) than the brown morph. The colourmorphs of Madracis pharensis did not differ in the number of released planulae ( $t$-test; $t=1.16, \mathrm{df}=285, \mathrm{p}=0.25$ ) and produced equally sized planula ( $t$-test; $t=-0.37, \mathrm{df}=56, \mathrm{p}=0.70$ ).

\section{Temperature and planulae release}

In Curaçao, the average annual seawater temperature is $27.43^{\circ} \mathrm{C}\left(\mathrm{SD}=1.14\right.$, range 24.95 to $29.58^{\circ} \mathrm{C}$ ). Since large daily fluctuations occur in the number of planulae, we used a monthly average to relate the number of planulae to seawater temperature (Figs. 4 \& 5) as well as spawning intensity (i.e. the number of planulae produced per $\mathrm{cm}^{2}$ ). A positive relationship between spawning intensity (Fig. 5) and temperature was revealed for all species $\left(\mathrm{R}^{2}>0.33 ; \mathrm{p}<0.05, \mathrm{n}=13\right.$; $\mathrm{n}=9$ for the green morph of Madracis pharensis), except $M$. senaria. This relation was significant only when the number of planulae was related to the seawater temperature of the preceding month. The spawning intensity of $M$. senaria showed no relation with the average seawater temperature of the preceding month, because of the peaks in planulae release in October and November $\left(R^{2}=0.03, p=0.60, n=13\right)$. Lag periods longer than 1 mo did not result in significant relations between temperature and spawning frequency or intensity.

\section{Lunar cycle and planulae release}

Only the larval release of Madracis senaria was related to the lunar cycle. Planulae release differed between the different lunar weeks $\left(\chi^{2}=18.79, \mathrm{df}=3, \mathrm{p}<0.001\right)$ and was highest around the last-quarter moon (Fig. 6). Because $M$. senaria released $>95 \%$ of its planulae on Lunar Days 21 and 26 in the months October and November, the relation was found in these months only; Lunar Nights 21 and 26 are the same nights on which many broadcast-spawning Caribbean coral species participate in the annual coral mass spawning (van Veghel 1994, deGraaf et al. 1999). None of the other Madracis species showed a lunar pattern in larval release, and the percentage of spawning colonies was highly variable on a daily scale, ranging between 0 and $67 \%$, independent of lunar phase.

\section{DISCUSSION}

This study quantified the timing of planulation and the number of planulae released for 4 closely related coral species of Madracis in Curaçao. Comparative studies on the reproductive behaviour of closely related species have previously been largely restricted to species that spawn gametes instead of brooding planulae: e.g. the Montastrea species-complex (van Veghel 1994, Knowlton et al. 1997), Acropora sp. (Willis et al. 1997a,b) and Porites sp. (Kojis \& Quinn 1981). An exception is the work by van Moorsel (1983), who elegantly illustrated how the use of differences in reproductive strategies can be used to distinguish between closely related brooding species. Since we gathered our data daily in situ for $1 \mathrm{yr}$, we were able to show the degree to which the 4 Madracis species differ in their reproductive strategies. In general, interspecific differences are small, which corresponds to Harrison's (1985) hypothesis that reproductive strategies follow phylogenetic lineages. Nevertheless, small interspecific differences in planulae number and timing of spawning do exist between the different Madracis species. 

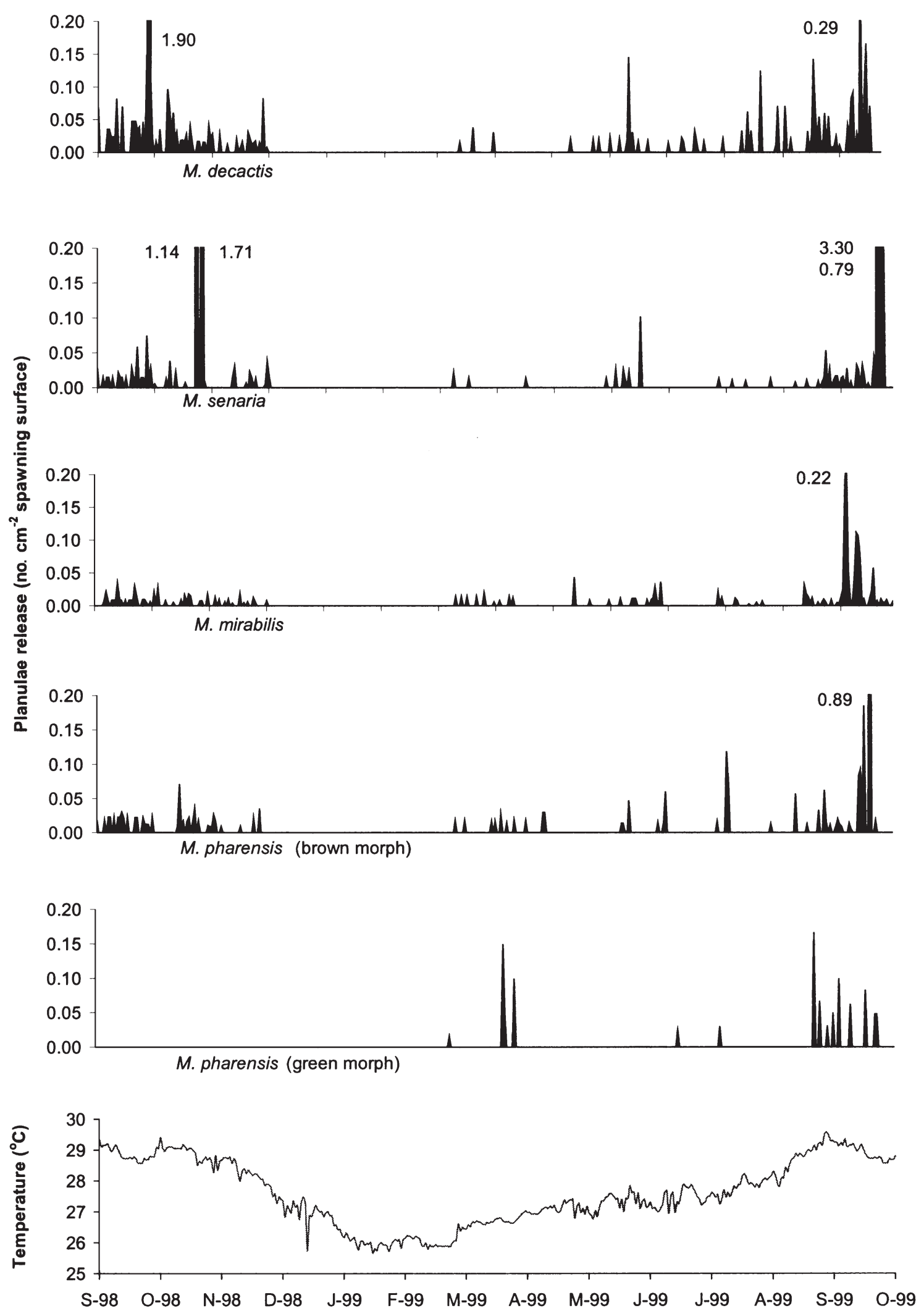

Fig. 4. Madracis spp. Daily planulae release for all species from 18 September 1998 to 8 November 1999 at Buoy Zero, SW coast of Curaçao. Temperature was measured daily at 12:00 h 

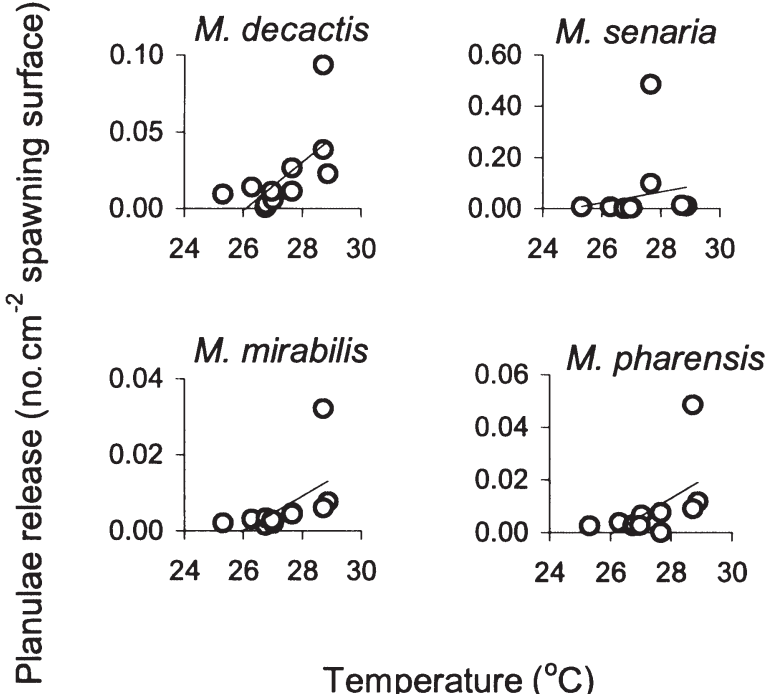

\section{Temperature $\left({ }^{\circ} \mathrm{C}\right)$}

Fig. 5. Madracis spp. Relation between average number of planulae released (daily data pooled for each month) and water temperature of the preceding month for all species. Temperature was measured daily at 12:00 $\mathrm{h}$

\section{Planulae production and fecundity}

Of all 4 species only Madracis senaria and $M$. mirabilis differ in fecundity, although their ranges overlap with those of the other species (Table 3). The time needed to produce a new planula is on average more than $1 \mathrm{yr}$ (except for $M$. senaria), which suggests that not all polyps reproduce synchronously every year. The presence of only 1 planula per polyp has also been found for Pocillopora damicornis (Tanner 1996). Another pocilloporid characteristic found in Madracis spp. is the independence of the number of planulae produced from colony size (Table 2). Peak production of individual colonies, independent of size, is mainly responsible for the absence of this relation, and Tanner (1996) found similar patterns for P. damicornis. Planulae production in Madracis spp. corresponds to values found for other brooding species: 0.03 to 0.20 planulae $\mathrm{cm}^{-2} \mathrm{~d}^{-1}$ for Porites asteroides (McGuire 1998) and 0.03 to 0.12 planulae $\mathrm{cm}^{-2} \mathrm{~d}^{-1}$ for 2 agaricid species (van Moorsel 1983). Within the genus, species that depend most on fragmentation, i.e. M. mirabilis and M. pharensis (Vermeij \& Bak 2003b), produce the lowest number of planulae.

\section{Larval size}

Planulae size is identical between species, except for Madracis decactis, whose planulae are nearly twice as large as those of the other species. Madracis spp. plan- ulae are among the smallest known for scleractinian corals (Fadlallah 1983, Harrison \& Wallace 1990). The volumetric size of planulae of another pocilloporid, Pocillopora damicornis, is 3 times larger than that of Madracis spp. planulae. Madracis species therefore combine low levels of planulae release with small planulae size, making them successful recruiters of available space. The scleractinian fauna (colonial and solitary corals) on settlement racks positioned at our study site consisted of $22.8 \%$ Madracis species ( $\mathrm{n}=127$; M.J.A.V. unpubl. data). This indicates that Madracis planulae, despite their small size, are indeed successful colonizers relative to other brooding and spawning species.

\section{Timing of planulae release}

Temperature, photoperiod, lunar, tidal and seasonal cycles have been proposed as temporal cues, regulating planulae release within populations (Kojis \& Quinn 1981, Jokiel et al. 1985, Willis et al. 1985, Hunter 1989). Unlike many other pocilloporids, the members of the Madracis genus show no lunar periodicity, except for M. senaria. All species release planulae nearly all year round, from March to December, with peak release in the months September to November. This pattern has also been found for other Caribbean brooding species (van Moorsel 1983). Planulae release correlated with seawater temperature with a lag period of 1 mo. The onset of gamete production is directly dependent on seawater temperature, and it takes approximately 1 mo for the oocytes to mature. Maturation is followed by quick planula release when eggs are fertilized (Vermeij et al. 2003a). A second-order nature of planulae release has also been suggested for Favia fragum (Szmant-Froelich et al. 1985), in which the release of sperm is directly related to the lunar cycle. McGuire (1998) found an identical relation between planulae release and seawater temperatures of the preceding month prior to planulae release for Porites asteroides. Planulae release and seawater temperature are indirectly related through gametogenesis, and this indirect relation occurs widely in brooding taxa.

The genetic confirmation of Madracis senaria as a true species (Diekmann et al. 2001) corresponds to its different pattern of planulae release compared to the other Madracis species. M. senaria has a lunar pattern of planulae release superimposed on a seasonal cycle and spawns more planulae than all other species. The simultaneous release of many planulae can be advantageous in terms of predator satiation, i.e. preventing planulae from being consumed by predators (Harrison et al. 1984). Other brooding species that release many (>100) larvae simultaneously also show lunar 

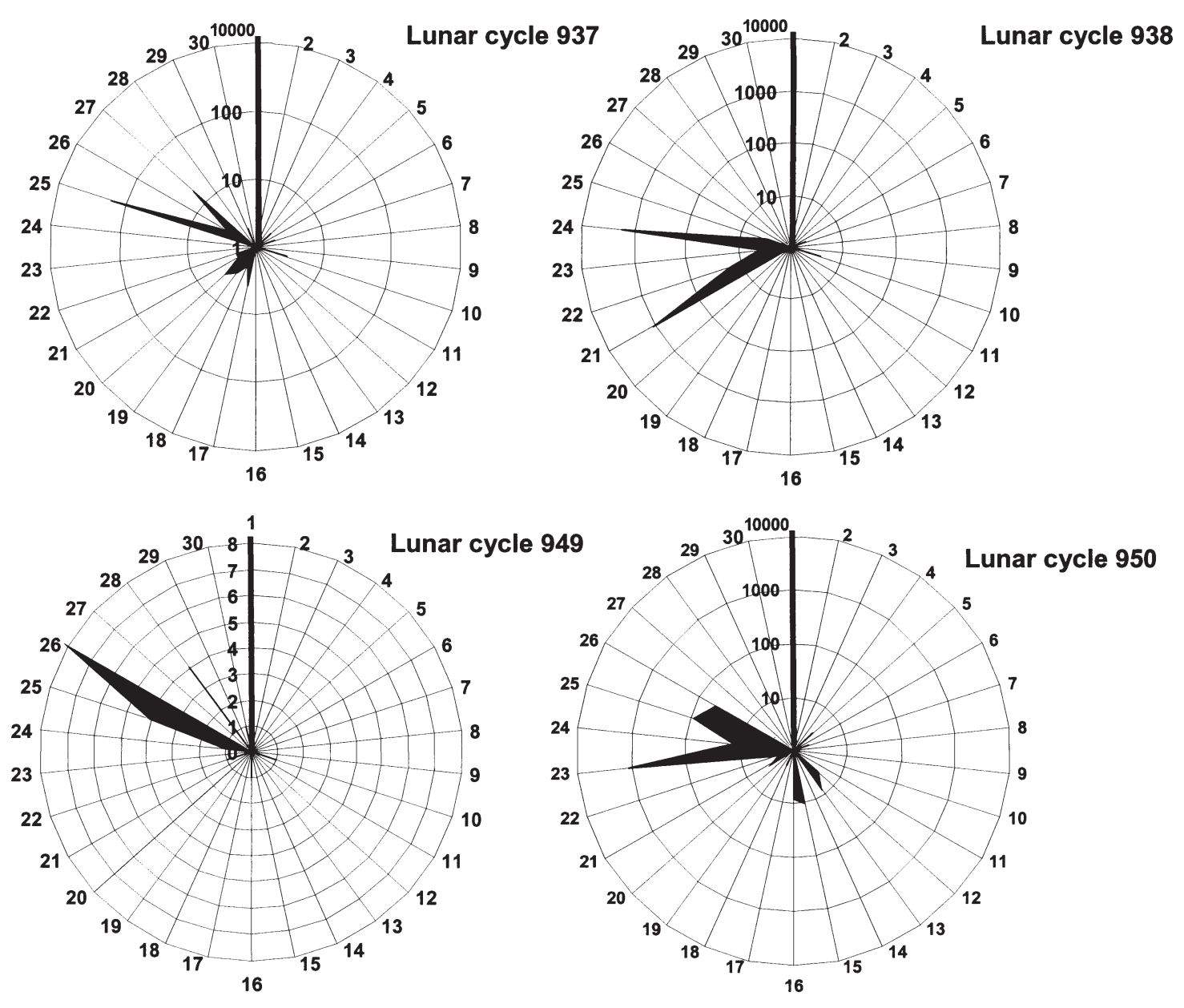

Fig. 6. Madracis senaria. Timing of larval release of in relation to Lunar Days 0 to 30 for the 4 lunar cycles (LC) with maximum planulae release: $\mathrm{LC} 937=20.09 .98$ to $19.10 .98 ; \mathrm{LC} 938=20.10 .98$ to $18.11 .98 ; \mathrm{LC} 949=09.09 .99$ to $08.10 .99 ; \mathrm{LC} 950=09.10 .99$ to 07.11 .99 . Maximum release took place around the last quarter moon (Day 23). Note the logarithmic scale indicates the number of planulae spawned by all colonies $d^{-1}(n=12-15)$. New moon $=$ Lunar Day 1 ; first quarter is Lunar Day 8 ; full moon is Lunar Day 17; last quarter is Lunar Day 23

periodicity (Szmant-Froelich et al. 1985, McGuire 1998). Lunar cycles supposedly synchronize gamete release to increase fertilization success, but this function is of no importance in brooding corals. We suggest that a relationship exists between the amount of reproductive output, i.e. number of gametes or planulae, and the organisation of their release. In brooding species we distinguish 2 patterns of planulae release: (1) species that release many planulae (such as $M$. senaria and Porites asteroides; McGuire 1998) organise their planulae release to prevent their offspring from being eaten by predators; (2) species with low reproductive output, such as all other Madracis species or agaricids (van Moorsel 1983), do not require such organization to induce predation satiation; this explains the absence of lunar release patterns in these species.

The superimposition of a lunar cycle over a seasonal cycle for Madracis senaria, whereas all other Madracis species only show a seasonal cycle, suggests that lunar cycles are probably younger in the evolutionary timescale in this genus.

\section{Demographic consequences of spawning patterns}

The occurrence of peaks in planulae release affects the size frequency distribution of Madracis senaria populations (Bak \& Meesters 1998, Meesters et al. 2001). In a parallel study on the demography of $\mathrm{Ma}$ dracis species, the colony size $\left(\mathrm{cm}^{2}\right)$ of all M. senaria colonies $(n=132)$ was measured in a $30 \times 1 \mathrm{~m}$ belt transect along the $20 \mathrm{~m}$ isobath at our study site in December 1999, i.e. 1 or 2 mo after the October and November spawning. Two peaks occured in the size classes 0.04 to 0.08 and 0.16 to $0.32 \mathrm{~cm}^{2}$, probably resulting from the 2 recruitment peaks following the October 
and November spawning peaks. This shows that a species' spawning strategy can be reflected in its population size frequency distribution depending on the time of the year (Vermeij \& Bak 2003a,b). The regular, non-fluctuating pattern of planula release in the other Madracis species never resulted in recruitment peaks in their size frequency distributions (M.J.A.V. unpubl. data).

\section{In conclusion}

Madracis species release planulae from March to December, i.e. during the period of increasing water temperatures, with maximum release from September to November. Only for $M$. senaria does a lunar pattern exist. M. senaria spawns $>98 \%$ of its planulae during the last quarter moon. Interspecific differences in fecundity are small and only significant between $M$. senaria and $M$. mirabilis. The recent taxonomic reclassification of Madracis sp. from the pocilloporid to the astronicoenid family is currently being debated (Veron 2000). Gametogenic similarities (Vermeij et al. 2003a) and characteristics of planulae release argue for positioning of the Madracis sp. in the pocilloporid family. Their brooding reproductive strategy can be divided into 2 sub-strategies: (1) organized mass release; (2) gradual release in low numbers without any pattern. This indicates that the reproductive strategies of closely related species harbour previously neglected subtleties that could be essential for understanding their ecology and evolution.

Acknowledgements. We thank the Carmabi Foundation for logistical support and facilities. We are grateful to G. Nieuwland, J. Smelt and I. de Vries for practical assistance.

\section{LITERATURE CITED}

Ayre DJ, Hughes TP, Standish RS (1997) Genetic differentiation, reproductive mode, and gene flow in the brooding coral Pocillopora damicornis along the Great Barrier Reef, Australia. Mar Ecol Prog Ser 159:175-187

Bak RPM, Meesters EH (1998) Coral population structure: the hidden information of colony size-frequency distributions. Mar Ecol Prog Ser 162:301-306

deGraaf M, Geertjes GJ, Videler JJ (1999) Observations on spawning of scleractinian corals and other invertebrates on the reefs of Bonaire (Netherlands Antilles, Caribbean). Bull Mar Sci 64:189-194

Diekmann OE, Bak RPM, Stam WT, Olsen JL (2001) Molecular genetic evidence for reticulate speciation in the coral genus Madracis from a Caribbean fringing reef slope. Mar Biol 139:221-233

Fadlallah YH (1983) Sexual reproduction, development, larval biology in scleractinian corals: a review. Coral Reefs 2: $129-150$

Fenner DP (1993) Species distinctions among several Caribbean stony corals. Bull Mar Sci 53:1099-1116
Harrison PL (1985) Sexual characteristics of scleractinian corals: systematic, evolutionary implications. Proc 5th Int Coral Reef Congr 4:337-342

Harrison PL, Wallace CC (1990) Reproduction, dispersal recruitment of scleractinian corals. In: Dubinsky Z (ed) Ecosystems of the world 25. Coral Reefs. Elsevier, Amsterdam, p 133-208

Harrison PL, Babcock RC, Dull GD, Oliver JK, Wallace CC, Willis BL (1984) Mass spawning in tropical reef corals. Science 223:1186-1189

Hunter CL (1989) Environmental cues controlling spawning in two Hawaiian corals, Montipora verrucosa and $M$. dilatata. Proc 6th Int Coral Reef Symp 2:727-732

Jokiel PL, Ito RY, Liu PM (1985) Night irradiance and synchronization of lunar release of panula larvae in the reef coral Pocillopora damicornis. Mar Biol 88:167-174

Kenyon JC (1997) Models of reticulate evolution in the coral genus Acropora based on chromosome numbers: parallels with plants. Evolution 51:756-767

Knowlton N, Maté JL, Guzmán HM, Rowan R, Jara J (1997) Direct evidence for reproductive isolation among the three species of the Montastraea annularis complex in Central America (Panamá and Honduras). Mar Biol 127:705-711

Kojis BL, Quinn NJ (1981) Reproductive strategies in four species of Porites (Scleractinia). The reef and man. Proc 4th Int Coral Reef Symp 2:145-151

Kruger A, Schleyer MH (1998) Sexual reproduction in the coral Pocillopora verrucosa (Cnidaria, Scleractinia) in KwaZulu-Natal, South Africa. Mar Biol 132:703-710

McGuire MP (1998) Timing of larval release by Porites asteroides in the northern Florida Keys. Coral Reefs 17: 369-375

Meesters EH, Hilterman M, Kardinaal E, Keetman M, de Vries M, Bak RPM (2001) Colony size-frequency distributions of scleractinian coral populations: spatial and interspecific variation. Mar Ecol Prog Ser 209:43-54

Moran NA (1992) The evolutionary maintenance of alternative phenotypes. Am Nat 139(5):971-989

Odorico DM, Miller DJ (1997) Variation in the ribosomal internal transcribed spacers and 5.8S rDNA among five species of Acropora (Cnidaria; Scleractinia): patterns of variation consistent with reticulate evolution. Mol Biol Evol 14:465-473

Richmond RH, Hunter CL (1990) Reproduction and recruitment of corals: comparisons among the Caribbean, the tropical Pacific, and the Red Sea. Mar Ecol Prog Ser 60:1-2

Shlesinger Y, Goulet TL, Loya Y (1998) Reproductive patterns of scleractinian corals in the northern Red Sea. Mar Biol 132:691-701

SPSS (2000) SYSTAT 10. SPSS Science, Chicago, IL

Stearns SC (1992) The evolution of life histories. Oxford University Press, Oxford

Szmant AM (1986) Reproductive ecology of Caribbean reef corals. Coral Reefs 5:43-54

Szmant-Froelich A, Riggs L, Reutter M (1985) Sexual reproduction of Favia fragum (Esper): lunar patterns of gametogenesis, embryogenesis and planulation in Puerto Rico. Bull Mar Sci 37:880-892

Tanner JE (1996) Seasonality and lunar periodicity in the reproduction of pocilloporid corals. Coral Reefs 15:59-66

van Moorsel GWNM (1983) Reproductive strategies in two closely related stony corals (Agaricia, Scleractinia). Mar Ecol Prog Ser 13:273-283

van Veghel MLJ (1994) Reproductive characteristics of the polymorphic Caribbean reef building coral Montastrea annularis. 1. Gametogenesis and spawning behaviour. Mar Ecol Prog Ser 109:209-219 
Vermeij MJA, Bak RPM (2003a) Species-specific population structure of closely related coral morphospecies along a depth gradient (5-60 m) over a Caribbean reef slope. Bull Mar Sci (in press)

Vermeij MJA, Bak RPM (2003b) Inferring demographic processes from population size structure in corals. Proc 9th Int Coral Reef Symp (in press)

Vermeij MJA, Bröker $K$, Nijgh de Sampayo E, Bak RPM (2002) Patterns in reproductive biology of closely related coral species: gametogenesis in Madracis. Coral Reefs (in press)

Vermeij MJA, Delvoye L, Nieuwland G, Bak RPM (2003a) Patterns in fluorescence over a Caribbean Reef slope: the coral genus Madracis. Photosynthetica 40(3):423-429

Vermeij MJA, Diekmann OE, Bak RPM (2003b) A new species of scleractinian coral (Cnidaria, Anthozoa), Madracis carmabi, form the southern Caribbean. Bull Mar Sci (in press)

Veron JEN (1995) Corals in space and time. Cornell University Press, Ithaca, NY

Editorial responsibility: Otto Kinne (Editor),

Oldendorf/Luhe, Germany
Veron JEN (2000) Corals of the world, Part I-III, Australian Institute of Marine Science, Townsville

Ward S (1992) Evidence for broadcast spawning as well as brooding in the scleractinian coral Pocillopora damicornis. Mar Biol 112:641-646

Wells JW (1973a) New and old scleractinian corals from Jamaica. Bull Mar Sci 23:16-55

Wells JW (1973b) Two new hermatypic corals from the West Indies. Bull Mar Sci 23:925-932

Willis B, Babcock RC, Harrison PL, Oliver JK (1985) Patterns in the mass spawning of corals on the Great Barrier Reef from 1981 to 1984. Proc 5th Int Coral Reef Congr 4:343-348

Willis BL, Babcock RC, Harrison PL, Wallace C (1997a) Hybridization and breeding incompatibilities within the mating systems of mass spawning reef corals. Proc 8th Int Coral Reef Symp 1:81-90

Willis BL, Babcock RC, Harrison PL, Wallace CC (1997b) Experimental hybridization and breeding incompatibilities within the mating systems of mass spawning reef corals. Coral Reefs 16:S53-S65

Submitted: August 9, 2001; Accepted: May 31, 2002

Proofs received from author(s): January 10, 2003 